\title{
Orexin receptors in GtoPdb v.2021.3
}

Paul Coleman ${ }^{1}$, Luis de Lecea ${ }^{2}$, Anthony Gotter ${ }^{1}$, Jim Hagan ${ }^{3}$, Daniel Hoyer ${ }^{4}$, Thomas Kilduff ${ }^{5}$, Jyrki P. Kukkonen ${ }^{6}$, Rod Porter ${ }^{3}$, John Renger ${ }^{1}$, Jerome M Siegel $^{7}$, Gregor Sutcliffe ${ }^{2}$, Neil Upton ${ }^{3}$ and Christopher J. Winrow ${ }^{1}$

1. Merck Research Laboratories, USA

2. Scripps Research Institute, USA

3. GlaxoSmithKline, UK

4. University of Melbourne, Australia

5. SRI International, USA

6. University of Helsinki, Finland

7. University of California Los Angeles, USA

\begin{abstract}
Orexin receptors (nomenclature as agreed by the NC-IUPHAR Subcommittee on Orexin receptors [42]) are activated by the endogenous polypeptides orexin-A and orexin-B (also known as hypocretin-1 and -2; 33 and 28 aa) derived from a common precursor, preproorexin or orexin precursor, by proteolytic cleavage and some typical peptide modifications [109]. Currently the only orexin receptor ligands in clinical use are suvorexant and lemborexant, which are used as hypnotics. Orexin receptor crystal structures have been solved [134, 133, 54, 117, 46].
\end{abstract}

\section{Contents}

This is a citation summary for Orexin receptors in the Guide to Pharmacology database (GtoPdb). It exists purely as an adjunct to the database to facilitate the recognition of citations to and from the database by citation analyzers. Readers will almost certainly want to visit the relevant sections of the database which are given here under database links.

GtoPdb is an expert-driven guide to pharmacological targets and the substances that act on them. GtoPdb is a reference work which is most usefully represented as an on-line database. As in any publication this work should be appropriately cited, and the papers it cites should also be recognized. This document provides a citation for the relevant parts of the database, and also provides a reference list for the research cited by those parts. For further details see [19].

Please note that the database version for the citations given in GtoPdb are to the most recent preceding version in which the family or its subfamilies and targets were substantially changed. The links below are to the current version. If you need to consult the cited version, rather than the most recent version, please contact the GtoPdb curators.

\section{Database links}

Orexin receptors

https://www.guidetopharmacology.org/GRAC/FamilyDisplayForward?familyId=51

Introduction to Orexin receptors

https://www.guidetopharmacology.org/GRAC/FamilyIntroductionForward?familyId=51

Receptors

$\mathrm{OX}_{1}$ receptor

https://www.guidetopharmacology.org/GRAC/ObjectDisplayForward?objectId=321

$\mathrm{OX}_{2}$ receptor

https://www.guidetopharmacology.org/GRAC/ObjectDisplayForward?objectId=322

\section{References}


1. Abbas MG, Shoji H, Soya S, Hondo M, Miyakawa T and Sakurai T. (2015) Comprehensive Behavioral Analysis of Male Ox1r (-/-) Mice Showed Implication of Orexin Receptor-1 in Mood, Anxiety, and Social Behavior. Front Behav Neurosci 9: 324 [PMID:26696848]

2. Akanmu MA and Honda K. (2005) Selective stimulation of orexin receptor type 2 promotes wakefulness in freely behaving rats. Brain Res 1048: 138-45 [PMID:15919057]

3. Akbari E, Naghdi N and Motamedi F. (2006) Functional inactivation of orexin 1 receptors in CA1 region impairs acquisition, consolidation and retrieval in Morris water maze task. Behav Brain Res 173: 47-52 [PMID:16815564]

4. Ammoun S, Holmqvist T, Shariatmadari R, Oonk HB, Detheux M, Parmentier M, Akerman KE and Kukkonen JP. (2003) Distinct recognition of OX1 and OX2 receptors by orexin peptides. $J$ Pharmacol Exp Ther 305: 507-14 [PMID:12606634]

5. Ammoun S, Johansson L, Ekholm ME, Holmqvist T, Danis AS, Korhonen L, Sergeeva OA, Haas HL, Akerman KE and Kukkonen JP. (2006) OX1 orexin receptors activate extracellular signalregulated kinase in Chinese hamster ovary cells via multiple mechanisms: the role of $\mathrm{Ca} 2+$ influx in OX1 receptor signaling. Mol Endocrinol 20: 80-99 [PMID:16141359]

6. Ammoun S, Lindholm D, Wootz H, Akerman KE and Kukkonen JP. (2006) G-protein-coupled OX1 orexin/hcrtr-1 hypocretin receptors induce caspase-dependent and -independent cell death through p38 mitogen-/stress-activated protein kinase. J Biol Chem 281: 834-42 [PMID:16282319]

7. Asahi S, Egashira S, Matsuda M, Iwaasa H, Kanatani A, Ohkubo M, Ihara M and Morishima H. (2003) Development of an orexin-2 receptor selective agonist, [Ala(11), D-Leu(15)]orexin-B. Bioorg Med Chem Lett 13: 111-3 [PMID:12467628]

8. Backberg M, Hervieu G, Wilson S and Meister B. (2002) Orexin receptor-1 (OX-R1) immunoreactivity in chemically identified neurons of the hypothalamus: focus on orexin targets involved in control of food and water intake. Eur J Neurosci 15: 315-328 [PMID:11849298]

9. Bayer L, Eggermann E, Serafin M, Saint-Mleux B, Machard D, Jones B and Mühlethaler M. (2001) Orexins (hypocretins) directly excite tuberomammillary neurons. Eur J Neurosci 14: 1571-5 [PMID:11722619]

10. Bergman JM, Roecker AJ, Mercer SP, Bednar RA, Reiss DR, Ransom RW, Meacham Harrell C, Pettibone DJ, Lemaire W and Murphy KL et al.. (2008) Proline bis-amides as potent dual orexin receptor antagonists. Bioorg Med Chem Lett 18: 1425-30 [PMID:18207395]

11. Beuckmann CT, Sinton CM, Williams SC, Richardson JA, Hammer RE, Sakurai T and Yanagisawa M. (2004) Expression of a poly-glutamine-ataxin-3 transgene in orexin neurons induces narcolepsy-cataplexy in the rat. J Neurosci 24: 4469-77 [PMID:15128861]

12. Bingham S, Davey PT, Babbs AJ, Irving EA, Sammons MJ, Wyles M, Jeffrey P, Cutler L, Riba I and Johns A et al.. (2001) Orexin-A, an hypothalamic peptide with analgesic properties. Pain 92: 81-90 [PMID:11323129]

13. Blanco M, López M, GarcIa-Caballero T, Gallego R, Vázquez-Boquete A, Morel G, SeñarIs R, Casanueva F, Diéguez C and Beiras A. (2001) Cellular localization of orexin receptors in human pituitary. J Clin Endocrinol Metab 86: 1616-9 [PMID:11443222]

14. Bonaventure P, Shelton J, Yun S, Nepomuceno D, Sutton S, Aluisio L, Fraser I, Lord B, Shoblock $\mathrm{J}$ and Welty N et al.. (2015) Characterization of JNJ-42847922, a Selective Orexin-2 Receptor Antagonist, as a Clinical Candidate for the Treatment of Insomnia. J Pharmacol Exp Ther 354: 471-82 [PMID:26177655]

15. Boss C, Roch-Brisbare C, Steiner MA, Treiber A, Dietrich H, Jenck F, von Raumer M, Sifferlen T, Brotschi C and Heidmann B et al.. (2014) Structure-activity relationship, biological, and pharmacological characterization of the proline sulfonamide ACT-462206: a potent, brainpenetrant dual orexin 1/orexin 2 receptor antagonist. ChemMedChem 9: 2486-96 [PMID:25147058]

16. Bourgin P, Huitrón-Résendiz S, Spier AD, Fabre V, Morte B, Criado JR, Sutcliffe JG, Henriksen SJ and de Lecea L. (2000) Hypocretin-1 modulates rapid eye movement sleep through activation of locus coeruleus neurons. J Neurosci 20: 7760-5 [PMID:11027239]

17. Boutrel B, Kenny PJ, Specio SE, Martin-Fardon R, Markou A, Koob GF and de Lecea L. (2005) Role for hypocretin in mediating stress-induced reinstatement of cocaine-seeking behavior. Proc Natl Acad Sci USA 102: 19168-73 [PMID:16357203]

18. Brisbare-Roch C, Dingemanse J, Koberstein R, Hoever P, Aissaoui H, Flores S, Mueller C, Nayler O, van Gerven J, de Haas SL, Hess P, Qiu C, Buchmann S, Scherz M, Weller T, Fischli W, Clozel $M$ and Jenck F. (2007) Promotion of sleep by targeting the orexin system in rats, dogs and humans. Nat Med 13: 150-5 [PMID:17259994]

19. Buneman P, Christie G, Davies JA, Dimitrellou R, Harding SD, Pawson AJ, Sharman JL and Wu Y. (2020) Why data citation isn't working, and what to do about it Database 2020 [PMID:32367113]

20. Burdakov D, Liss B and Ashcroft FM. (2003) Orexin excites GABAergic neurons of the arcuate nucleus by activating the sodium--calcium exchanger. J Neurosci 23: 4951-7 [PMID:12832517]

21. Caillol M, Aioun J, Baly C, Persuy MA and Salesse R. (2003) Localization of orexins and their 
receptors in the rat olfactory system: possible modulation of olfactory perception by a neuropeptide synthetized centrally or locally. Brain Res 960: 48-61 [PMID:12505657]

22. Callander GE, Olorunda M, Monna D, Schuepbach E, Langenegger D, Betschart C, Hintermann S, Behnke D, Cotesta S and Fendt M et al.. (2013) Kinetic properties of "dual" orexin receptor antagonists at OX1R and OX2R orexin receptors. Front Neurosci 7: 230 [PMID:24376396]

23. Chemelli RM, Willie JT, Sinton CM, Elmquist JK, Scammell T, Lee C, Richardson JA, Williams SC, Xiong Y and Kisanuki Y et al.. (1999) Narcolepsy in orexin knockout mice: molecular genetics of sleep regulation. Cell 98: 437-51 [PMID:10481909]

24. Chen J and Randeva HS. (2004) Genomic organization of mouse orexin receptors: characterization of two novel tissue-specific splice variants. Mol Endocrinol 18: 2790-804 [PMID:15256537]

25. Christopher JA, Aves SJ, Brown J, Errey JC, Klair SS, Langmead CJ, Mace OJ, Mould R, Patel JC and Tehan BG. (2015) Discovery of HTL6641, a dual orexin receptor antagonist with differentiated pharmacodynamic properties Medicinal Chemistry Communications 6: 947-955

26. Clark JW, Brian ML, Drummond SPA, Hoyer D and Jacobson LH. (2020) Effects of orexin receptor antagonism on human sleep architecture: A systematic review. Sleep Med Rev 53: 101332 [PMID:32505969]

27. Cluderay JE, Harrison DC and Hervieu GJ. (2002) Protein distribution of the orexin-2 receptor in the rat central nervous system. Regul Pept 104: 131-44 [PMID:11830288]

28. Cox CD, Breslin MJ, Whitman DB, Schreier JD, McGaughey GB, Bogusky MJ, Roecker AJ, Mercer SP, Bednar RA, Lemaire W, Bruno JG, Reiss DR, Harrell CM, Murphy KL, Garson SL, Doran SM, Prueksaritanont T, Anderson WB, Tang C, Roller S, Cabalu TD, Cui D, Hartman GD, Young SD, Koblan KS, Winrow CJ, Renger JJ and Coleman PJ. (2010) Discovery of the dual orexin receptor antagonist [(7R)-4-(5-chloro-1,3-benzoxazol-2-yl)-7-methyl-1,4-diazepan-1-yl][5-methyl-2-(2H1,2,3-triazol-2-yl)phenyl]methanone (MK-4305) for the treatment of insomnia.J Med Chem 53: 5320-32 [PMID:20565075]

29. Dalrymple MB, Jaeger WC, Eidne KA and Pfleger KD. (2011) Temporal profiling of orexin receptor-arrestin-ubiquitin complexes reveals differences between receptor subtypes. $J$ Biol Chem 286: 16726-33 [PMID:21378163]

30. Darker JG, Porter RA, Eggleston DS, Smart D, Brough SJ, Sabido-David C and Jerman JC. (2001) Structure-activity analysis of truncated orexin-A analogues at the orexin-1 receptor. Bioorg Med Chem Lett 11: 737-40 [PMID:11266181]

31. de Lecea L, Kilduff TS, Peyron C, Gao X, Foye PE, Danielson PE, Fukuhara C, Battenberg EL, Gautvik VT and Bartlett FS et al.. (1998) The hypocretins: hypothalamus-specific peptides with neuroexcitatory activity. Proc Natl Acad Sci USA 95: 322-7 [PMID:9419374]

32. Di Fabio R, Pellacani A, Faedo S, Roth A, Piccoli L, Gerrard P, Porter RA, Johnson CN, Thewlis K and Donati D et al.. (2011) Discovery process and pharmacological characterization of a novel dual orexin 1 and orexin 2 receptor antagonist useful for treatment of sleep disorders. Bioorg Med Chem Lett 21: 5562-7 [PMID:21831639]

33. Duxon MS, Stretton J, Starr K, Jones DN, Holland V, Riley G, Jerman J, Brough S, Smart D and Johns A et al.. (2001) Evidence that orexin-A-evoked grooming in the rat is mediated by orexin-1 (OX1) receptors, with downstream 5-HT2C receptor involvement. Psychopharmacology (Berl.) 153: 203-9 [PMID:11205420]

34. Eggermann E, Serafin M, Bayer L, Machard D, Saint-Mleux B, Jones BE and Mühlethaler M. (2001) Orexins/hypocretins excite basal forebrain cholinergic neurones. Neuroscience 108: 177 81 [PMID:11734353]

35. Ehrström M, Levin F, Kirchgessner AL, Schmidt PT, Hilsted LM, Grybäck P, Jacobsson H, Hellström PM and Näslund E. (2005) Stimulatory effect of endogenous orexin A on gastric emptying and acid secretion independent of gastrin. Regul Pept 132: 9-16 [PMID:16125803]

36. Ehrström M, Näslund E, Ma J, Kirchgessner AL and Hellström PM. (2003) Physiological regulation and NO-dependent inhibition of migrating myoelectric complex in the rat small bowel by OXA. Am J Physiol Gastrointest Liver Physiol 285: G688-G695 [PMID:12816759]

37. El Firar A, Voisin T, Rouyer-Fessard C, Ostuni MA, Couvineau A and Laburthe M. (2009) Discovery of a functional immunoreceptor tyrosine-based switch motif in a 7-transmembranespanning receptor: role in the orexin receptor OX1R-driven apoptosis. FASEB J 23: 4069-80 [PMID:19661287]

38. Eriksson KS, Sergeeva O, Brown RE and Haas HL. (2001) Orexin/hypocretin excites the histaminergic neurons of the tuberomammillary nucleus. J Neurosci 21: 9273-9 [PMID:11717361]

39. Faedo S, Perdonà E, Antolini M, di Fabio R, Merlo Pich E and Corsi M. (2012) Functional and binding kinetic studies make a distinction between OX1 and OX2 orexin receptor antagonists. Eur J Pharmacol 692: 1-9 [PMID:22796453]

40. FDA. FDA approves new type of sleep drug, Belsomra

41. Fitch TE, Benvenga MJ, Jesudason CD, Zink C, Vandergriff AB, Menezes MM, Schober DA and Rorick-Kehn LM. (2014) LSN2424100: a novel, potent orexin-2 receptor antagonist with selectivity over orexin-1 receptors and activity in an animal model predictive of antidepressant- 
like efficacy. Front Neurosci 8: 5 [PMID:24478625]

42. Foord SM, Bonner TI, Neubig RR, Rosser EM, Pin JP, Davenport AP, Spedding M and Harmar AJ. (2005) International Union of Pharmacology. XLVI. G protein-coupled receptor list. Pharmacol Rev 57: 279-88 [PMID:15914470]

43. Hara J, Beuckmann CT, Nambu T, Willie JT, Chemelli RM, Sinton CM, Sugiyama F, Yagami K, Goto K and Yanagisawa $\mathrm{M}$ et al.. (2001) Genetic ablation of orexin neurons in mice results in narcolepsy, hypophagia, and obesity. Neuron 30: 345-54 [PMID:11394998]

44. Harris GC, Wimmer M and Aston-Jones G. (2005) A role for lateral hypothalamic orexin neurons in reward seeking. Nature 437: 556-9 [PMID:16100511]

45. Haynes AC, Jackson B, Chapman H, Tadayyon M, Johns A, Porter RA and Arch JR. (2000) A selective orexin-1 receptor antagonist reduces food consumption in male and female rats. Regul Pept 96: 45-51 [PMID:11102651]

46. Hellmann J, Drabek M, Yin J, Gunera J, Pröll T, Kraus F, Langmead CJ, Hübner H, Weikert D and Kolb P et al.. (2020) Structure-based development of a subtype-selective orexin 1 receptor antagonist. Proc Natl Acad Sci U S A 117: 18059-18067 [PMID:32669442]

47. Hervieu GJ, Cluderay JE, Harrison DC, Roberts JC and Leslie RA. (2001) Gene expression and protein distribution of the orexin-1 receptor in the rat brain and spinal cord. Neuroscience 103: 777-97 [PMID:11274794]

48. Hirose M, Egashira S, Goto Y, Hashihayata T, Ohtake N, Iwaasa H, Hata M, Fukami T, Kanatani A and Yamada K. (2003) N-acyl 6,7-dimethoxy-1,2,3,4-tetrahydroisoquinoline: the first orexin-2 receptor selective non-peptidic antagonist. Bioorg Med Chem Lett 13: 4497-9 [PMID:14643355]

49. Hirota K, Kushikata T, Kudo M, Kudo T, Smart D and Matsuki A. (2003) Effects of central hypocretin-1 administration on hemodynamic responses in young-adult and middle-aged rats. Brain Res 981: 143-150 [PMID:12885435]

50. Hoang QV, Bajic D, Yanagisawa M, Nakajima S and Nakajima Y. (2003) Effects of orexin (hypocretin) on GIRK channels. J Neurophysiol 90: 693-702 [PMID:12702704]

51. Holmqvist T, Akerman KE and Kukkonen JP. (2002) Orexin signaling in recombinant neuron-like cells. FEBS Lett 526: 11-4 [PMID:12208495]

52. Holmqvist T, Akerman KE and Kukkonen JP. (2001) High specificity of human orexin receptors for orexins over neuropeptide Y and other neuropeptides. Neurosci Lett 305: 177-80 [PMID:11403934]

53. Holmqvist T, Johansson L, Ostman M, Ammoun S, Akerman KE and Kukkonen JP. (2005) OX1 orexin receptors couple to adenylyl cyclase regulation via multiple mechanisms. J Biol Chem 280: 6570-9 [PMID:15611118]

54. Hong C, Byrne NJ, Zamlynny B, Tummala S, Xiao L, Shipman JM, Partridge AT, Minnick C, Breslin MJ and Rudd MT et al.. (2021) Structures of active-state orexin receptor 2 rationalize peptide and small-molecule agonist recognition and receptor activation. Nat Commun 12: 815 [PMID:33547286]

55. Irukayama-Tomobe $\mathrm{Y}$, Ogawa $\mathrm{Y}$, Tominaga $\mathrm{H}$, Ishikawa $\mathrm{Y}$, Hosokawa N, Ambai S, Kawabe $\mathrm{Y}$, Uchida S, Nakajima R and Saitoh T et al.. (2017) Nonpeptide orexin type-2 receptor agonist ameliorates narcolepsy-cataplexy symptoms in mouse models. Proc Natl Acad Sci USA 114: 5731-5736 [PMID:28507129]

56. Ishibashi M, Takano S, Yanagida H, Takatsuna M, Nakajima K, Oomura Y, Wayner MJ and Sasaki K. (2005) Effects of orexins/hypocretins on neuronal activity in the paraventricular nucleus of the thalamus in rats in vitro. Peptides 26: 471-81 [PMID:15652654]

57. Johansson L, Ekholm ME and Kukkonen JP. (2007) Regulation of OX1 orexin/hypocretin receptor-coupling to phospholipase $\mathrm{C}$ by $\mathrm{Ca} 2+$ influx. Br J Pharmacol 150: 97-104 [PMID:17115071]

58. Johansson L, Ekholm ME and Kukkonen JP. (2008) Multiple phospholipase activation by OX(1) orexin/hypocretin receptors. Cell Mol Life Sci 65: 1948-56 [PMID:18488139]

59. Johnson PL, Federici LM, Fitz SD, Renger JJ, Shireman B, Winrow CJ, Bonaventure P and Shekhar A. (2015) OREXIN 1 AND 2 RECEPTOR INVOLVEMENT IN CO2 -INDUCED PANICASSOCIATED BEHAVIOR AND AUTONOMIC RESPONSES. Depress Anxiety 32: 671-83 [PMID:26332431]

60. Jones DN, Gartlon J, Parker F, Taylor SG, Routledge C, Hemmati P, Munton RP, Ashmeade TE, Hatcher JP and Johns A et al.. (2001) Effects of centrally administered orexin-B and orexin-A: a role for orexin-1 receptors in orexin-B-induced hyperactivity. Psychopharmacology (Berl.) 153: 210-8 [PMID:11205421]

61. Jäntti M, Putula J, Somerharju P, Frohman M and Kukkonen J. (2012) OX(1) orexin/hypocretin receptor activation of phospholipase D. BrJ Pharmacol 165: 1109-23 [PMID:21718304]

62. Jäntti MH, Putula J, Turunen PM, Näsman J, Reijonen S, Lindqvist C and Kukkonen JP. (2013) Autocrine endocannabinoid signaling through CB1 receptors potentiates OX1 orexin receptor signaling. Mol Pharmacol 83: 621-32 [PMID:23233488]

63. Karteris E, Machado RJ, Chen J, Zervou S, Hillhouse EW and Randeva HS. (2005) Food deprivation differentially modulates orexin receptor expression and signaling in rat 
hypothalamus and adrenal cortex. Am J Physiol Endocrinol Metab 288: E1089-100

[PMID:15687100]

64. Karteris E, Randeva HS, Grammatopoulos DK, Jaffe RB and Hillhouse EW. (2001) Expression and coupling characteristics of the $\mathrm{CRH}$ and orexin type 2 receptors in human fetal adrenals. $J$ Clin Endocrinol Metab 86: 4512-9 [PMID:11549701]

65. Kukkonen JP. (2016) OX2 orexin/hypocretin receptor signal transduction in recombinant Chinese hamster ovary cells. Cell Signal 28: 51-60 [PMID:26582739]

66. Kukkonen JP. (2016) G-protein-dependency of orexin/hypocretin receptor signalling in recombinant Chinese hamster ovary cells. Biochem Biophys Res Commun 476: 379-85 [PMID:27237973]

67. Kukkonen JP. (2013) Physiology of the orexinergic/hypocretinergic system: a revisit in 2012. Am J Physiol, Cell Physiol 304: C2-32 [PMID:23034387]

68. Kukkonen JP. (2017) Orexin/Hypocretin Signaling. Curr Top Behav Neurosci 33: 17-50 [PMID:27909990]

69. Kukkonen JP. (2016) G-protein inhibition profile of the reported Gq/11 inhibitor UBO-QIC. Biochem Biophys Res Commun 469: 101-7 [PMID:26614908]

70. Kukkonen JP and Akerman KE. (2001) Orexin receptors couple to Ca2+ channels different from store-operated Ca2 + channels. Neuroreport 12: 2017-20 [PMID:11435939]

71. Kukkonen JP and Leonard CS. (2014) Orexin/hypocretin receptor signalling cascades. $\mathrm{Br} \mathrm{J}$ Pharmacol 171: 314-31 [PMID:23902572]

72. Kunii K, Yamanaka A, Nambu T, Matsuzaki I, Goto K and Sakurai T. (1999) Orexins/hypocretins regulate drinking behaviour. Brain Res 842: 256-61 [PMID:10526122]

73. Langmead CJ, Jerman JC, Brough SJ, Scott C, Porter RA and Herdon HJ. (2004) Characterisation of the binding of [3H]-SB-674042, a novel nonpeptide antagonist, to the human orexin-1 receptor. Br J Pharmacol 141: 340-6 [PMID:14691055]

74. Larsson KP, Peltonen HM, Bart G, Louhivuori LM, Penttonen A, Antikainen M, Kukkonen JP and Akerman KE. (2005) Orexin-A-induced Ca2+ entry: evidence for involvement of trpc channels and protein kinase C regulation. J Biol Chem 280: 1771-81 [PMID:15537648]

75. Leonard CS and Kukkonen JP. (2014) Orexin/hypocretin receptor signalling: a functional perspective. Br J Pharmacol 171: 294-313 [PMID:23848055]

76. Lin L, Faraco J, Li R, Kadotani H, Rogers W, Lin X, Qiu X, de Jong PJ, Nishino S and Mignot E. (1999) The sleep disorder canine narcolepsy is caused by a mutation in the hypocretin (orexin) receptor 2 gene. Cell 98: 365-76 [PMID:10458611]

77. Lund PE, Shariatmadari R, Uustare A, Detheux M, Parmentier M, Kukkonen JP and Akerman KE. (2000) The orexin OX1 receptor activates a novel Ca2+ influx pathway necessary for coupling to phospholipase C. J Biol Chem 275: 30806-12 [PMID:10880509]

78. López M, Señarís R, Gallego R, García-Caballero T, Lago F, Seoane L, Casanueva F and Diéguez C. (1999) Orexin receptors are expressed in the adrenal medulla of the rat. Endocrinology 140: 5991-4 [PMID:10579367]

79. Magga J, Bart G, Oker-Blom C, Kukkonen JP, Akerman KE and Näsman J. (2006) Agonist potency differentiates $\mathrm{G}$ protein activation and $\mathrm{Ca} 2+$ signalling by the orexin receptor type 1 . Biochem Pharmacol 71: 827-36 [PMID:16430869]

80. Malherbe P, Borroni E, Gobbi L, Knust H, Nettekoven M, Pinard E, Roche O, Rogers-Evans M, Wettstein JG and Moreau JL. (2009) Biochemical and behavioural characterization of EMPA, a novel high-affinity, selective antagonist for the OX(2) receptor. Br J Pharmacol 156: 1326-41 [PMID:19751316]

81. Malherbe P, Borroni E, Pinard E, Wettstein JG and Knoflach F. (2009) Biochemical and electrophysiological characterization of almorexant, a dual orexin 1 receptor (OX1)/orexin 2 receptor (OX2) antagonist: comparison with selective OX1 and OX2 antagonists. Mol Pharmacol 76: 618-31 [PMID:19542319]

82. Malherbe P, Roche O, Marcuz A, Kratzeisen C, Wettstein JG and Bissantz C. (2010) Mapping the binding pocket of dual antagonist almorexant to human orexin 1 and orexin 2 receptors: comparison with the selective OX1 antagonist SB-674042 and the selective OX2 antagonist Nethyl-2-[(6-methoxy-pyridin-3-yl)-(toluene-2-sulfonyl)-amino]-N-pyridin-3-ylmethyl-acetamide (EMPA). Mol Pharmacol 78: 81-93 [PMID:20404073]

83. Marcus JN, Aschkenasi CJ, Lee CE, Chemelli RM, Saper CB, Yanagisawa M and Elmquist JK. (2001) Differential expression of orexin receptors 1 and 2 in the rat brain. J Comp Neurol 435: 6-25 [PMID:11370008]

84. McAtee LC, Sutton SW, Rudolph DA, Li X, Aluisio LE, Phuong VK, Dvorak CA, Lovenberg TW, Carruthers NI and Jones TK. (2004) Novel substituted 4-phenyl-[1,3]dioxanes: potent and selective orexin receptor $2(\mathrm{OX}(2) \mathrm{R})$ antagonists. Bioorg Med Chem Lett 14: 4225-9 [PMID:15261275]

85. Mikkelsen JD, Hauser F, deLecea L, Sutcliffe JG, Kilduff TS, Calgari C, Pévet P and Simonneaux V. (2001) Hypocretin (orexin) in the rat pineal gland: a central transmitter with effects on noradrenaline-induced release of melatonin. Eur J Neurosci 14: 419-25 [PMID:11553292] 
86. Milasta S, Evans NA, Ormiston L, Wilson S, Lefkowitz RJ and Milligan G. (2005) The sustainability of interactions between the orexin-1 receptor and beta-arrestin-2 is defined by a single C-terminal cluster of hydroxy amino acids and modulates the kinetics of ERK MAPK regulation. Biochem J 387: 573-84 [PMID:15683363]

87. Mould R, Brown J, Marshall FH and Langmead CJ. (2014) Binding kinetics differentiates functional antagonism of orexin-2 receptor ligands. Br J Pharmacol 171: 351-63 [PMID:23692283]

88. Nagahara $T$, Saitoh $T$, Kutsumura $N$, Irukayama-Tomobe $Y$, Ogawa $Y$, Kuroda $D$, Gouda $H$, Kumagai H, Fujii H and Yanagisawa M et al.. (2015) Design and Synthesis of Non-Peptide, Selective Orexin Receptor 2 Agonists. J Med Chem 58: 7931-7 [PMID:26267383]

89. Navarro G, Quiroz C, Moreno-Delgado D, Sierakowiak A, McDowell K, Moreno E, Rea W, Cai NS, Aguinaga D and Howell LA et al.. (2015) Orexin-corticotropin-releasing factor receptor heteromers in the ventral tegmental area as targets for cocaine. J Neurosci 35: 6639-53 [PMID:25926444]

90. Nishino S, Ripley B, Overeem S, Lammers GJ and Mignot E. (2000) Hypocretin (orexin) deficiency in human narcolepsy. Lancet 355: 39-40 [PMID:10615891]

91. Nowak KW, Strowski MZ, Switonska MM, Kaczmarek P, Singh V, Fabis M, Mackowiak P, Nowak $\mathrm{M}$ and Malendowicz LK. (2005) Evidence that orexins A and B stimulate insulin secretion from rat pancreatic islets via both receptor subtypes. Int J Mol Med 15: 969-72 [PMID:15870901]

92. Näsman J, Bart G, Larsson K, Louhivuori L, Peltonen H and Akerman KE. (2006) The orexin OX1 receptor regulates $\mathrm{Ca} 2+$ entry via diacylglycerol-activated channels in differentiated neuroblastoma cells. J Neurosci 26: 10658-66 [PMID:17050705]

93. Okumura T, Takeuchi S, Motomura W, Yamada H, Egashira Si S, Asahi S, Kanatani A, Ihara M and Kohgo Y. (2001) Requirement of intact disulfide bonds in orexin-A-induced stimulation of gastric acid secretion that is mediated by OX1 receptor activation. Biochem Biophys Res Commun 280: 976-81 [PMID:11162621]

94. Peltonen HM, Magga JM, Bart G, Turunen PM, Antikainen MS, Kukkonen JP and Akerman KE. (2009) Involvement of TRPC3 channels in calcium oscillations mediated by OX(1) orexin receptors. Biochem Biophys Res Commun 385: 408-12 [PMID:19464259]

95. Peyron C, Faraco J, Rogers W, Ripley B, Overeem S, Charnay Y, Nevsimalova S, Aldrich M, Reynolds D and Albin R et al.. (2000) A mutation in a case of early onset narcolepsy and a generalized absence of hypocretin peptides in human narcoleptic brains. Nat Med 6: 991-7 [PMID:10973318]

96. Porter RA, Chan WN, Coulton S, Johns A, Hadley MS, Widdowson K, Jerman JC, Brough SJ, Coldwell M and Smart D et al.. (2001) 1,3-Biarylureas as selective non-peptide antagonists of the orexin-1 receptor. Bioorg Med Chem Lett 11: 1907-10 [PMID:11459658]

97. Putula J and Kukkonen JP. (2012) Mapping of the binding sites for the OX1 orexin receptor antagonist, SB-334867, using orexin/hypocretin receptor chimaeras. Neurosci Lett 506: 111-5 [PMID:22079339]

98. Putula J, Pihlajamaa T and Kukkonen JP. (2014) Calcium affects OX1 orexin (hypocretin) receptor responses by modifying both orexin binding and the signal transduction machinery. $\mathrm{Br}$ J Pharmacol 171: 5816-28 [PMID:25132134]

99. Putula J, Turunen PM, Jäntti MH, Ekholm ME and Kukkonen JP. (2011) Agonist ligand discrimination by the two orexin receptors depends on the expression system. Neurosci Lett 494: 57-60 [PMID:21362456]

100. Rainero I, Gallone S, Valfrè W, Ferrero M, Angilella G, Rivoiro C, Rubino E, De Martino P, Savi L and Ferrone $\mathrm{M}$ et al.. (2004) A polymorphism of the hypocretin receptor 2 gene is associated with cluster headache. Neurology 63: 1286-8 [PMID:15477554]

101. Randeva HS, Karteris E, Grammatopoulos D and Hillhouse EW. (2001) Expression of orexin-A and functional orexin type 2 receptors in the human adult adrenals: implications for adrenal function and energy homeostasis. J Clin Endocrinol Metab 86: 4808-13 [PMID:11600545]

102. Rappas M, Ali AAE, Bennett KA, Brown JD, Bucknell SJ, Congreve M, Cooke RM, Cseke G, de Graaf C and Doré AS et al.. (2020) Comparison of Orexin 1 and Orexin 2 Ligand Binding Modes Using X-ray Crystallography and Computational Analysis. J Med Chem 63: 1528-1543 [PMID:31860301]

103. Rinne MK, Leino TO, Turku A, Turunen PM, Steynen Y, Xhaard H, Wallén EAA and Kukkonen JP. (2018) Pharmacological characterization of the orexin/hypocretin receptor agonist Nag 26. Eur J Pharmacol 837: 137-144 [PMID:30194937]

104. Rodgers RJ, Halford JC, Nunes de Souza RL, Canto de Souza AL, Piper DC, Arch JR, Upton N, Porter RA, Johns A and Blundell JE. (2001) SB-334867, a selective orexin-1 receptor antagonist, enhances behavioural satiety and blocks the hyperphagic effect of orexin-A in rats. Eur J Neurosci 13: 1444-52 [PMID:11298806]

105. Roecker AJ, Cox CD and Coleman PJ. (2016) Orexin Receptor Antagonists: New Therapeutic Agents for the Treatment of Insomnia. J Med Chem 59: 504-30 [PMID:26317591]

106. Roecker AJ, Mercer SP, Schreier JD, Cox CD, Fraley ME, Steen JT, Lemaire W, Bruno JG, Harrell 
CM and Garson SL et al.. (2014) Discovery of 5"'-chloro-N-[(5,6-dimethoxypyridin-2yl)methyl]-2,2':5',3'-terpyridine-3'-carboxamide (MK-1064): a selective orexin 2 receptor antagonist (2-SORA) for the treatment of insomnia. ChemMedChem 9: 311-22 [PMID:24376006]

107. Roecker AJ, Reger TS, Mattern MC, Mercer SP, Bergman JM, Schreier JD, Cube RV, Cox CD, Li D and Lemaire W et al.. (2014) Discovery of MK-3697: a selective orexin 2 receptor antagonist (2-SORA) for the treatment of insomnia. Bioorg Med Chem Lett 24: 4884-90 [PMID:25248679]

108. Rouet-Benzineb P, Rouyer-Fessard C, Jarry A, Avondo V, Pouzet C, Yanagisawa M, Laboisse C, Laburthe $\mathrm{M}$ and Voisin T. (2004) Orexins acting at native OX(1) receptor in colon cancer and neuroblastoma cells or at recombinant OX(1) receptor suppress cell growth by inducing apoptosis. J Biol Chem 279: 45875-86 [PMID:15310763]

109. Sakurai T, Amemiya A, Ishii M, Matsuzaki I, Chemelli RM, Tanaka H, Williams SC, Richardson JA, Kozlowski GP and Wilson S et al.. (1998) Orexins and orexin receptors: a family of hypothalamic neuropeptides and G protein-coupled receptors that regulate feeding behavior. Cell 92: 573-85 [PMID:9491897]

110. Savaskan E, Müller-Spahn F, Meier F, Wirz-Justice A and Meyer P. (2004) Orexins and their receptors in the human retina. Pathobiology 71: 211-6 [PMID:15263810]

111. Scammell TE and Winrow CJ. (2011) Orexin receptors: pharmacology and therapeutic opportunities. Annu Rev Pharmacol Toxicol 51: 243-66 [PMID:21034217]

112. Shoblock JR, Welty N, Aluisio L, Fraser I, Motley ST, Morton K, Palmer J, Bonaventure P, Carruthers NI and Lovenberg TW et al.. (2011) Selective blockade of the orexin-2 receptor attenuates ethanol self-administration, place preference, and reinstatement.

Psychopharmacology (Berl.) 215: 191-203 [PMID:21181123]

113. Smart D, Jerman JC, Brough SJ, Rushton SL, Murdock PR, Jewitt F, Elshourbagy NA, Ellis CE, Middlemiss DN and Brown F. (1999) Characterization of recombinant human orexin receptor pharmacology in a Chinese hamster ovary cell-line using FLIPR. Br J Pharmacol 128: 1-3 [PMID:10498827]

114. Smart D, Sabido-David C, Brough SJ, Jewitt F, Johns A, Porter RA and Jerman JC. (2001) SB334867-A: the first selective orexin-1 receptor antagonist. Br J Pharmacol 132: 1179-82 [PMID:11250867]

115. Steiner MA, Gatfield J, Brisbare-Roch C, Dietrich H, Treiber A, Jenck F and Boss C. (2013) Discovery and characterization of ACT-335827, an orally available, brain penetrant orexin receptor type 1 selective antagonist. ChemMedChem 8: 898-903 [PMID:23589487]

116. Steiner MA, Sciarretta C, Pasquali A and Jenck F. (2013) The selective orexin receptor 1 antagonist ACT-335827 in a rat model of diet-induced obesity associated with metabolic syndrome. Front Pharmacol 4: 165 [PMID:24416020]

117. Suno R, Kimura KT, Nakane T, Yamashita K, Wang J, Fujiwara T, Yamanaka Y, Im D, Horita S and Tsujimoto H et al.. (2018) Crystal Structures of Human Orexin 2 Receptor Bound to the Subtype-Selective Antagonist EMPA. Structure 26: 7-19.e5 [PMID:29225076]

118. Sunter D, Morgan I, Edwards CM, Dakin CL, Murphy KG, Gardiner J, Taheri S, Rayes E and Bloom SR. (2001) Orexins: effects on behavior and localisation of orexin receptor 2 messenger ribonucleic acid in the rat brainstem. Brain Res 907: 27-34 [PMID:11430882]

119. Tang J, Chen J, Ramanjaneya M, Punn A, Conner AC and Randeva HS. (2008) The signalling profile of recombinant human orexin-2 receptor. Cell Signal 20: 1651-61 [PMID:18599270]

120. Tran DT, Bonaventure P, Hack M, Mirzadegan T, Dvorak C, Letavic M, Carruthers N, Lovenberg T and Sutton SW. (2011) Chimeric, mutant orexin receptors show key interactions between orexin receptors, peptides and antagonists. Eur J Pharmacol 667: 120-8 [PMID:21679703]

121. Trivedi P, Yu H, MacNeil DJ, Van der Ploeg LH and Guan XM. (1998) Distribution of orexin receptor mRNA in the rat brain. FEBS Lett 438: 71-75 [PMID:9821961]

122. Turunen PM, Ekholm ME, Somerharju P and Kukkonen JP. (2010) Arachidonic acid release mediated by OX1 orexin receptors. Br J Pharmacol 159: 212-21 [PMID:20002100]

123. Turunen PM, Jäntti MH and Kukkonen JP. (2012) OX1 orexin/hypocretin receptor signaling through arachidonic acid and endocannabinoid release. Mol Pharmacol 82: 156-67 [PMID:22550093]

124. Voisin T, El Firar A, Fasseu M, Rouyer-Fessard C, Descatoire V, Walker F, Paradis V, Bedossa P, Henin D and Lehy T et al.. (2011) Aberrant expression of OX1 receptors for orexins in colon cancers and liver metastases: an openable gate to apoptosis. Cancer Res 71: 3341-51 [PMID:21415167]

125. Voisin T, El Firar A, Rouyer-Fessard C, Gratio V and Laburthe M. (2008) A hallmark of immunoreceptor, the tyrosine-based inhibitory motif ITIM, is present in the G protein-coupled receptor OX1R for orexins and drives apoptosis: a novel mechanism. FASEB J 22: 1993-2002 [PMID:18198212]

126. Voisin T, Firar AE, Avondo V and Laburthe M. (2006) Orexin-induced apoptosis: the key role of the seven-transmembrane domain orexin type 2 receptor. Endocrinology 147: 4977-84 [PMID:16857748]

127. Wayner MJ, Armstrong DL, Phelix CF and Oomura Y. (2004) Orexin-A (Hypocretin-1) and leptin 
enhance LTP in the dentate gyrus of rats in vivo. Peptides 25: 991-6 [PMID:15203246]

128. Willie JT, Chemelli RM, Sinton CM, Tokita S, Williams SC, Kisanuki YY, Marcus JN, Lee C, Elmquist JK and Kohlmeier KA et al.. (2003) Distinct narcolepsy syndromes in Orexin receptor-2 and Orexin null mice: molecular genetic dissection of Non-REM and REM sleep regulatory processes. Neuron 38: 715-30 [PMID:12797957]

129. Winrow CJ, Gotter AL, Cox CD, Tannenbaum PL, Garson SL, Doran SM, Breslin MJ, Schreier JD, Fox SV and Harrell CM et al.. (2012) Pharmacological characterization of MK-6096 - A dual orexin receptor antagonist for insomnia. Neuropharmacology 62: 978-87 [PMID:22019562]

130. Wong KK, Ng SY, Lee LT, Ng HK and Chow BK. (2011) Orexins and their receptors from fish to mammals: a comparative approach. Gen Comp Endocrinol 171: 124-30 [PMID:21216246]

131. Wu M, Zhang Z, Leranth C, Xu C, van den Pol AN and Alreja M. (2002) Hypocretin increases impulse flow in the septohippocampal GABAergic pathway: implications for arousal via a mechanism of hippocampal disinhibition. J Neurosci 22: 7754-65 [PMID:12196599]

132. Yamamoto T, Nozaki-Taguchi N and Chiba T. (2002) Analgesic effect of intrathecally administered orexin-A in the rat formalin test and in the rat hot plate test. Br J Pharmacol 137: 170-6 [PMID:12208773]

133. Yin J, Babaoglu K, Brautigam CA, Clark L, Shao Z, Scheuermann TH, Harrell CM, Gotter AL, Roecker AJ and Winrow CJ et al.. (2016) Structure and ligand-binding mechanism of the human OX1 and OX2 orexin receptors. Nat Struct Mol Biol 23: 293-9 [PMID:26950369]

134. Yin J, Mobarec JC, Kolb P and Rosenbaum DM. (2015) Crystal structure of the human OX2 orexin receptor bound to the insomnia drug suvorexant. Nature 519: 247-50 [PMID:25533960]

135. Yoshida Y, Naoe Y, Terauchi T, Ozaki F, Doko T, Takemura A, Tanaka T, Sorimachi K, Beuckmann CT and Suzuki M et al.. (2015) Discovery of (1R,2S)-2-\{[(2,4-Dimethylpyrimidin-5yl)oxy]methyl\}-2-(3-fluorophenyl)-N-(5-fluoropyridin-2-yl)cyclopropanecarboxamide (E2006): A Potent and Efficacious Oral Orexin Receptor Antagonist. J Med Chem 58: 4648-64 [PMID:25953512]

136. Young JK, Wu M, Manaye KF, Kc P, Allard JS, Mack SO and Haxhiu MA. (2005) Orexin stimulates breathing via medullary and spinal pathways. J Appl Physiol 98: 1387-95 [PMID:15557013]

137. Yukitake H, Fujimoto T, Ishikawa T, Suzuki A, Shimizu Y, Rikimaru K, Ito M, Suzuki M and Kimura H. (2019) TAK-925, an orexin 2 receptor-selective agonist, shows robust wakepromoting effects in mice. Pharmacol Biochem Behav 187: 172794 [PMID:31654653]

138. Zhu Y, Miwa Y, Yamanaka A, Yada T, Shibahara M, Abe Y, Sakurai T and Goto K. (2003) Orexin receptor type-1 couples exclusively to pertussis toxin-insensitive G-proteins, while orexin receptor type- 2 couples to both pertussis toxin-sensitive and -insensitive G-proteins. J Pharmacol Sci 92: 259-266 [PMID:12890892] 